\title{
Jälleenrakennuskauden väestöpoliittiset tehtävät
}

\author{
Kirjoittanut V. J. Sukselainen.
}

Se uusi vaihe, jonka vuonna 1944 solmittu välirauhansopimus kansamme elämässä aloitti, merkitsee valtavan jälleenrakennuskauden alkamista ja monien vaativien tehtävien avautumista kaikilla aloilla. Huolenpito maan väestön kehityksestä on kautta aikojen kuulunut valtion tehtäviin, mutta varsinkin tällaisina käännekausina, jolloin kansan on ponnistettava voimansa joidenkin suurten ja ratkaisevien päämäärien saavuttamiseksi, kiintyy huomio väestöpolitiikkaan ja sen ajankohtaisiin tehtäviin. Onhàn kansa tärkein valtion kolmesta elementistä. Ellei olisi kansaa, ei tarvittaisi kahta muutakaan elementtiä, ei maata sen paremmin kuin valtiovaltaakaan. Siksi täytyy jokaiseen järkevään ja johdonmukaiseen jälleenrakennussuunnitelmaan sisältyä myös väestöä kohdanneiden vaurioiden korjaaminen.

Tästä on meillä hyvänä esimerkkinä se väestöpoliittisen lainsäädännön uudistus, joka itäisessä naapurimaassamme jo vuonna 1944 pantiin alulle ja jonka tehtävänä on turvata Neuvostoliiton väestön terve kasvu. Vastaavia toimenpiteitä voimme täydellä syyllä odottaa myös läntisissä suurvalloissa, joissa Venäjän väestöpolitiikka jo on herättänyt melkoista huomiota ja joilla pienemmistä miehistötappioistaan huolimatta on enemmän kuin Venäjällä syytä olla väestönkehityksestänsä huolissaan. Maan vastaista taloudellista kehitystä silmällä pitäen on myös läntisessä naapurimaassamme Ruotsissa kiinnitetty suurta huomiota taisteluun väes- 
tönkasvun hidastumista ja kansan lukumääräistä vähenemistä vastaan. Näin on luonnollisesti tehtävä meidänkin maassamme, jossa harva asutus on pahimpia taloudellisen ja yhteiskunnallisen kehityksen jarruja ja jonka väestökantaa sota lisäksi on raskaasti verottanut.

Niistä keinoista, joilla taistelua hitaasti hiipivää väestön kasvun vähenemistä vastaan on käytävä, di meidän maassamme sen paremmin kuin muuallakaan näytä olevan sanottavaa erimielisyyttä. Jos esim. tarkastelemme väestöpoliittisia toimenpiteitä kummassakin naapurimaassamme, Venäjällä ja Ruotsissa, huomaamme niiden olevan suunnilleen samanlaisia kuin omat vastaavat toimenpiteemme. Eroa on oikeastaan vain päämäärän asettelussa. Ruotsin väestöpolitiikka ilmoittaa tavoitteekseen vain väestökannan säilyttämisen nykyisellään. Neuvostoliitossa kuten meilläkin sen sijaan halutaan lisätä väestöä, koska tajutaan, että maan käyttämättömät luonnonvarat voi vain nykyistä suurempi văestö kyllin tehokkaasti ottaa kulttuurin palvelukseen.

Sen jälkeen kun luonnollinen vietti ei enää yksin määrää väestön kasvusta, tulee väestöpoliittisen valistustyön astua esiin, selvittää väestön merkitystä yhteiskunnalle ja vedota jokaisen kansalaisen yhteiskunnalliseen vastuuntuntoon. Tämä yksinänsä ei kuitenkaan riitä. Väestöpropagandan rinnalla tarvitaan väestöpolitiikkaa, valtion toimenpiteitä, jotka tähtäävät sosiaalisen turvallisuuden lisäämiseen perheenhuoltajain keskuudessa sekä perhekustannusten tasoittamiseen.

Mitä varsinaiseen väestöpropagandaan tulee, se tuntuu olevan monelle kompastuskivenä. Näyttää olevan paljon ihmisiä, jotka ovat kiinnittäneet huomionsa väestöpropagandaan, mutta eivät ole seuranneet sosiaalista kehitystä eivätkä tunne niitä väestöpoliittisia toimenpiteitä, joihin maassamme jo on ryhdytty. Ei ole kovin pitkää aikaa siitä, kun eräs tunnettu pakinoitsija vielä kirjoitti, että Väestöliiton tarkoituksena on saada ihmiset »silmät ummessa lisäämään jälkeläistensä lukua». Tämä väite ei tehnyt Väestöliitolle oikeutta ja toivottavasti sen esittäjäkin verraten pian huomasi, että tasarinnan väestöpoliittisen valistustyön kanssa on koetettu taistella sosiaalisen turvallisuuden lisäämisen ja perhekustannusten tasoittamisen puolesta. 
Suomessa on seutuja, joissa kaikenlainen väestönlisäämispropaganda on tarpeetonta, koska väestö mutenkin lisääntyy tyydyttävästi, ellei suorastaan liikaa. Toisaalta on kuitenkin myös seutuja, kuten kaikki asutuskeskukset ja suuret osat Uudenmaan, Turun ja Porin sekä Hämeen läänin maaseutua, joissa kaivataan väestöpoliittista valistustyötä varsin kipeästi. Näillä alueilla asuu paljon väkeä, jotka elävät siksi hyvissä taloudellisissa oloissa, etteivät edes sotavuosien poikkeuksellisissa oloissa ole köyhyydellä voineet lapsettomuuttaan tai lastensa vähäistä lukumäärää puolustaa.

Jokaisen on myös helppo huomata, että väestöpoliittinen valistustyö ei ole vältettävissä, jos kerran halutaan kansanvaltaisessa maassa saada aikaan sosiaalisia uudistuksia väestönkasvulle myönteisessä hengessä. Demokraattisissa oloissa ei voida tällaisia kysymyksiä vaieten hoitaa, vaan niistä on puhuttava, kunnes tarpeellinen mielipiteiden syvämuokkaus on saatu aikaan ja mieliala kypsynyt niille yhteiskunnallisille uudistuksille, joiden suorittaminen on väestökysymyksen hoitamisen ehdoton edellytys. Niistä ei vuida vaieta, ennenkuin riittävä sosiaalinen turvallisuus saavutetaan ja perhekustannukset saadaan kohtuullisesti tasatuiksi.

On kuitenkin huomattava, että sosiaalinen turvattomuus ei kurjissa ja alkeellisissa oloissa yleensä ole lapsirajoituksen syynä. Päinvastoin on lapsijoukko useasti sitä suurempi, mitä pienemmät edellytykset sen kasvattamiseen ovat. Vasta sen jälkeen kun taloudellinen vastuuntunto kasvaa ja lapsirajoituksen teknilliset mahdollisuudet alkavat tulla tunnetuiksi, lisääntyy sosiaalisen turvattomuuden merkitys lapsilukua rajoittavana tekijänä. Sosiaalisen turvallisuuden vaatimus tulee sitä merkittävämmäksi tekijäksi, mitä enemmän yleinen valistuneisuus lisääntyy.

On näin ollen pyrittävä luomaan olosuhteet perheenmuodostumiselle suotuisiksi ja lisäämään sosiaalista turvallisuutta, ennenkuin voidaan odottaa, että keskimääräinen lapsiluku vähävaraisissa perheissä - perheiden enemmistössä - vastaisuudessa pysyisi ennallaan tai nykyisestään lisääntyisi. Jos tarkastellaan keskimääräistä lapsilukua eri yhteiskuntaluokissa ja asutustyypeissä, havaitaan, että maaseutu voittaa kaupungin ja että maataviljelevällä väestöllä on suurimmat luontaiset edellytykset lapsien kasvatta- 
miseen. Tämä väestö saa suuren osan elintarvikkeita omasta tuotannostaan. Se voi käyttää taloudellisesti sen muuten markkinattoman työvoiman, jota lapset edustavat. Kustannukset lasta kohden muodostuvat näin ollen maanviljelijäperheissä huokeammiksi kuin muualla.

Toisin on usein laita kaupungeissa ja niihin verrattavissa asutuskeskuksissa, joissa työttömyyden uhka viime vuosikymmeninä on suuressa määrässä levittänyt sosiaalisen turvattomuuden tunnetta. Kun työ loppuu, eivät lopu yksin mahdollisuudet saada ruokaa, vaarassa on myös häätö asunnosta. Pyrittäessä luomaan suotuisia olosuhteita perheenmuodostukselle on ensimmäisiä edellytyksiä, että yhteiskunta ennakollisesti takaa jokaiselle työnhaluiselle jatkuvan työnsaantimahdollisuuden.

Keskeisin jälleenrakennuskysymyksemme, maan hankkiminen kotinsa menettäneelle maataloussiirtoväelle sekä nuille maaseudulla elämään tottuneille rintamamiehille, jotka haluavat jäädä maatalousammattiin, on myös mitä suurimmassa määrässä väestöpoliittinen kysymys. Ne, jotka ovat erehtyneet arvostelemaan asutustoimintaa yksinomaan tuotannon kannalta, ovat päätyneet arviointiin, jonka kuullessaan kansantalousmies pakostakin muistaa Simonde de Sismondin huudahduksen: „Onko sitten omaisuus kaikki eikä ihminen mitään». Jos asutustoimintaa tarkastellaan yhteiskuntatalouden eikä pelkän tuotantoprosessin kannalta, on otettava huomioon, että jokainen uusi maatila merkitsee myös uutta kotia eikä yksinomaan uutta tuotantoyksikköä.

Toinen tärkeä jälleenrakennuskauden tehtävä, jolla myös on väestöpoliittisesti perustavalaatuinen merkitys, on teollisten ja kaupallisten elinkeinojen piiriin kuuluvien laitosten sijaintikysymys. On tyypillisesti tähänastisen käsityskannan mukaista, että siirtoväen sijoituksessa unohdettiin kokonaan kaupunkilaissiirtoväen tarpeet. Maataloussiirtoväen kohdalta ryhdyttiin heti asuttamistoimiin, katsottiin yhteiskunnan asiaksi sijoittaa heidät määrätyn suunnitelman mukaisesti maan jäljellejääneeseen osaan. Kaupunkien asujamisto sen sijaan siirrettiin umpimähkäisesti eräisiin maaseutupitäjiin, joissa sillä ei useasti ollut juuri mitään mahdollisuuksia elinkeinonsa harjoittamiseen. Välttämättömyyden pakosta sen oli omin avuin ruvettava hakeutumaan asutuskeskuk- 
siin työtä saadakseen. Näin on esim. maan asuntopulan vaivaamaan pääkaupunkiin hakeutunut paljon enemmän luovutetun alueen asukkaita kuin olisi ollut tarpeellista ja tarkoituksenmukaista.

Alkaa kuitenkin käydä yhä ilmeisemmäksi, että sijaintikysymys on otettava esille laajemmassakin mielessä kuin vain kaupunkilaissiirtoväen kysymyksenä. Jos tahdotaan saada olot maassamme perheenmuodostukselle suotuisiksi ja yleensäkin halutaan kiinnittää enemmän huomiota itse ihmiseen, hänen viihtymiseensä ja hänen elämäntapojensa terveyteen ja luonnollisuuteen, ei voida antaa väen virrata maaseudulta asutuskeskuksiin nykyisellä vauhdilla eikä ilman tiettyä suunnitelmallisuutta.

Maataloudesta vapautuu vuosittain väkeä, koska maataloustekniikalla meiłän maassamme näyttää olevan ilmeiset mahdollisuudet edistyä nopeammin kuin maataloustuotanto voi laajentua ja monipuolistua. Siksi meidän on kaikessa talouspoliittisessa ja siis myös väestöpoliittisessa suunnittelussä otettava huomioon, että niin kauan kuin maaseudun väestö vähänkin lisääntyy ja maataloustekniikka kehittyy, maataloudesta siirtyy vuosittain väkeä muihin ammatteihin. Ei kuitenkaan ole mụtään järkeä antaa tämän uutta sijoitusta etsivän väen ahtautua kaupunkeihin, ei ainakaan Helsinkiin, jossa jo ennestään asuu noin kymmenes osa kansastamme, koska se paljon mukavammin ja terveellisemmin sekä vähemmin kustannuksin voi asua ja työskennellä sopivasti sijoitettuna pienempiin asutuskeskuksiin tai varsinaiselle maaseudulle.

Näin ollen on jälleenrakennuskauden tärkeimpiä talouspoliittisia tehtäviä tarkoituksenmukainen seutukuntasuunnittelu, jossa teollisuusläitosten ja muiden joukkotyöpaikkojen sijoittelussa otetaan huomioon myös ihminen eikä yksinomaan tuotanto ja jossa muistetaan, että ihminen on myös taloudenpidon aihe eikä yksin sen väline.

Nykyisin vallitsee kaikissa asutuskeskuksissamme huutava asuntopula. Se on luonnollista, koska asuntokantaa ei sotavuosina ole voitu normaalilla tavalla lisätä eikä uudistaa ja koska sïrtoväki kokonaisuudessaan on sijoitettu vanhoihin asuntoihin entisten asukkaiden lisäksi. Tilanteen parantamiseksi on pakko niin pian kuin mahdollisuudet myöten antavat panna alulle suurisuuntainen asunnonrakennustoiminta. On eräässä mielessä onnellistakin, että 
rakennusmahdollisuudet sotaa seuraavina vuosina ovat minimaalisen pienet. Jos taloudellisia mahdollisuuksia asuntopulan laajasuuntaiseen lieventämiseen olisi heti välirauhan jälkeen auennut, olisi jo tähän mennessä rakennettu määrättömästi asuntoja sinne, minne väkeä jostakin syystä on tarpeettoman paljon ahtautunut. Olisi esim. suurennettu ennestäänkin liian suurta Helsinkiä tolkuttomasti vetämällä sinne sekä rakennustyöläisiä että-asuntoa vailla olevia ihmisiä sieltä, missä asuntopulan torjuminen ei olisi ollut yhtä ripeässä vauhdissa.

Rakennusaineiden puute on antanut aikaa ajatella. Erään arvion mukaan puuttuisi asutuskeskuksistamme noin 52.000 asuntoa ja veisi tämän vajauksen täyttäminen hyvän matkaa toista vuosikymmentä. Kun asia on tätä suuruusluokkaa, meillä on vielä mahdollisuuksia harkita, onko nyt välttämätöntä rakentaa kaikki nämä puuttuvat huoneistot niille paikkakunnille, joilla asuntopula on kirein. Ilmeisesti olisi târkoituksenmukaisempaa pyrkiä edes jonkinlaiseen suunnitelmaan lähivuosina rakennettavien tuotantolaitosten, koulujen, virastojen ym. joukkotyöskentelypaikkojen sijoittamiseksi. Siten ratkeaisi myös huomattavan huoneistomäärän sijoitus.

Aloite olisi tietenkin valtion tehtävä. Voitaisiin ajatella, että virastoasiain valtuutettu saisi tehtäväkseen tutkia, mitä valtion virastoja ja laitoksia voitaisiin siirtää pois pääkaupungista ja minkälaisissa ryhmissä ne olisi siirrettävä, jotta niiden työteho ja työskentelymahdollisuudet eivät pysyväisesti tästä toimenpiteestä kärsisi. Yhdessä näiden laitosten kanssa siirtyisi huomattava määrä perheitä pois Helsingistä. Tälle väestölle rakennettaisiin niin halvalla ja niin tarkoituksenmukaisesti kuin voidaan asunnot uudelle sijoituspaikkakunnalle. Toimenpidettä ei tarvitsisi rajoittaa yksin Helsinkiin. Sen voisi ulottaa muihinkin suurempiin asuntopulan vaivaamiin asutuskeskuksiin.

Kun valtio ottaisi aloitteen, sillä olisi mahdollisuuksia vaikuttaa myös yksityisiin järjestöihin, jotta nekin ottaisivat terveen desentralisaation ohjelmaansa. Valtiovallan toimesta voitaisiin niillekin suositella määrätynlaista sijoitussuunnitelmaa. Myös teollisuuslaitosten sijoittamisessa olisi useimmiten mahdollisuuksia ottaa entistä enemmän myös työntekijä huomioon ja rakentaa uudet lai- 
tokset sellaisille seuduille, joilla omakotitoiminnan ja siihen liittyvien etuuksien avulla saataisiin ihmiset juurtumaan määrätylle paikkakunnalle ja herätettäisiin heissä sitä sosiaalisen turvallisuuden tunnetta, minkä oma tupa ja oma lupa antaa. Samalla kun täten voitaisiin vähentää suurten asutuskeskusten kasvua, voitaisiin myös kiinnittää entistä suurempaa huomiota kaupunkien asemakavaan ja rakennusten soveltuvaisuuteen perheellisille. Voitaisiin entistä tarmokkaammin taistella asumiskustannusten nousua vastaan ja parantaa yleistä asumistasoa.

Samalla kun edellämainittuun tapaan olisi luotava suuntaviivoja asutuskeskusten olojen järjestelylle, olisi huomio kiinnitettävä myös tämän kysymyssarjan alkusyyhyn, maaltapakoilmiöön. Tällä ilmiöllä, kuten edellä olen viitannut, on reaalinen pohjansa siinä, että maalaiskodeista olosuhteiden pakosta vuosittain siirtyy väkeä varsinaisen maatalousammatin ulkopuolelle. Väestöliitto on vähäisessä mitasssa pannut alulle maaltapakoilmiön selvittämisen, ja tutkijain saamat vaikutelmat puoltavat vahvasti sitä ennakkokäsitystä, että tärkein syy maaltapakoon on ansiomahdollisuuksien puute tai ansioiden niukkuus. Toissijaisia tuntuvat olevan monet niistä syistä, joihin maaltapaon useasti esitetään pohjautuvan, ja toisarvoisia ne keinot, joita tämän ilmiön vastustamiseksi esitetään. Saattaa tuntua siltä, että moni muuttaa kaupunkiin pitkiä työpäiviä pakoon. Saattaa nünikään tuntua siltä, että moni lähtee etsimään huvituksia. Perussyy on kuitenkin taloudellista laatua, vaikka asianomainen maaltamuuttaja itsekin asian muulla tavalla esittäisi. Siksi eivät muut parannuskeinotkaan auta kuin ansiomahdollisuuksien järjestäminen maaseudulle sekä maaseudun varttuvan nuorison tarkoituksenmukainen ohjaus elämänuran valinnassa. Tällaisen ohjauksen avulla olisi koetettava suunnata nuorten harrastus niiden mahdollisuuksien hyväksikäyttöön, joita kotiseutu tyydyttävän toimeentulon saamiseksi voi tarjota.

Maaltapakoilmiön tutkiminen ja maataloudesta vuosittain irtaantuvan väestöaineksen sijoittaminen tutkimustulosten pohjalla luodun suunnitelman mukaisesti tarjoaa laajan ja tärkeän työkentän alkaneena jälleenrakennuskautena. Jos tämä jälleenrakennustyön puoli lyödään laimin, mahdollisuudet epäterveen keskitty- 
misilmiön vastustamiseksi käyvät vähäisiksi ja työ sosiaalisen turvallisuuden aikaansaamiseksi jää puolitiehen.

Lisäämällä ihmisten sosiaalista turvallisuutta, luomalla heille mahdollisimman suotuisat olosuhteet lasten kasvattamiseen sekä herättämällä heissä käsitys kansalaisvelvollisuuksistaan nousevan polven kasvattamisessa tehdään perustavaa laatua olevaa väestöpoliittista työtä. Tämä työ ei kuitenkaan vielä riitä. Ei riitä, että ihmiselle järjestetään mahdollisuus hankkia omaa maata, oma mökki tai oma osakehuoneisto. Ei riitä, että hänen kotinsa sijoitetaan terveelliseen ympäristöön ja hänen ansiomahdollisuuksiaan parannetaan. Kaikesta tästä huolimatta jää jäljelle se, että perheellinen huomaa joutuvansa elämään niukemmin kuin se, jolla ei ole lapsia tai jolla niitä on vain pari kolme.

Näin ei saisi /olla. Jos yhteiskunta kerran tunnustaa, että lasten kasvattaminen on kansalaisvelvollisuus, niin nykyaikainen oikeuskäsitys vaatii, että tällaisen yhteiskunnallisen velvollisuuden täyttämisestä aiheutuvien kustannusten täytyy mahdollisimman tasan jakaantua yhteiskunnan jäsenten kesken. Perhekustannusten tasoittaminen toisin sanoen on välttämättömyys, josta ei enää päästä.

Kaikkein vaatimattomin perhekustannusten tasoittamisen muoto on perheellisyyden huomioon ottaminen verotuksessa. Tässä ei vielä oikeastaan ole kysymys varsinaisesta tasoituksesta, vaan julkisoikeudellisen yhteisön aiheuttaman rasituksen jakamisesta verovelvollisten suorituskykyä vastaavalla tavalla. Tätä vaatii oikeudenmukaisuuden periaate, joka veroteoriassa on keskeinen.

Niinkuin toisessa tämän julkaisun kirjoituksessa on osoitettu, kysymys perheellisten verotuksesta on sotavuosina ollut maassamme kiinteästi esillä ja verraten huomattaviinkin saavutuksiin on tällä alalla päästy. Useita tärkeitä tehtäviä on kuitenkin vielä siirtynyt jälleenrakennuskauteen. Näistä on kiireellisimpiä kunnallisverotuksen uudistaminen ja siihen liittyvä kunnallisen verorasituksen tasoitus. Kun perheiden keskimääräinen lapsiluku suuresti vaihtelee maan eri osissa ja on yleensä suurin siellä, missä varallisuus on vähäisin, ei perheellisyyden perusteella annettavia vähennyksiä saada köyhissä runsaslapsisissa kunnissa riittävän suuriksi, ellei tarpeellista tasoitusta kuntien kesken saada aikaan. 
Välilliset verot ovat useimmiten sellaisia, että ne rasittavat verovelvollista sitä enemmän, mitä suurempi perhe hänellä on huollettavanaan. Ne toisin sanoen kasvavat veronmaksukyvyn vähetessä. Siksipä raskaaksi muodostuneen välillisen verotuksen alentamiseen on ryhdyttävä niin pian kuin siihen valtion taloudellisen aseman parantuessa suinkin mahdollisuuksia aukenee.

Varsinainen perhekustannusten tasoitus on tarkoitettu perhelisälain määräysten pohjalla tapahtuvaksi. Niinkuin toisaalla tässä julkaisussa esitetään, perhelisälain toimeenpanosta on saatu paljon myönteisiä kokemuksia, joskaan toimeenpano ei vielä ole lähelläkään ihannettaan. Varsinkin sen jälkeen kun perhelisä vuoden 1946 alusta alkaen nimellisesti suurennettiin ja laki samalla ulotettiin neljän lapsen perheisiin saakka, tilannetta on pidettävä entistä heikompana. Perhelisän korotus ei nimittäin merkinnyt muuta kuin niukkaa inflaatiomenetysten korvausta perheellisille. Varsinaista korotusta, jonka tärkeyttä esim. Väestöliitto vuodesta vuoteen oli tähdentänyt, ei suoritettu. Ne valtion varat, jotka tähän tarkoitukseen olisivat olleet käytettävissä, varattiin lain vaikutuspiirin laajentamiseen. Perhelisä ulotettiin neljän lapsen perheisiin, joita on suunnilleen yhtä paljon kuin sitä suurempia perheitä yhteensä. Lain tehoa toisin sanoen ei sanottavasti saatu lisätyksi, mutta sen sijaan kyllä toimenpiteestä valtiotaloudelle aiheutuvaa rasitusta, erittäinkin hallintokustannuksia, kun verraten mitätöntä tasoitussummaa jaetaan kaksi kertaa niin suurelle piirille kuin aikaisemmin.

Perhelisän määrän korottaminen tulee tästä syystä edelleen olemaan yhtenä väestöpolitiikan päivänkysymyksistä, kunnes päästään sellaiseen summaan, että sen avulla voidaan esim. viljelyshuolto tyydyttävästi järjestää. Päiväjärjestyksessä on myös edelleen perhelisän tekeminen yleiseksi eli huoltoavustuksen luonteen riistäminen siltä. Vuonna 1943 annettu perhelisälaki rajoitettiin väestöpoliitikkojen vastalauseista huolimatta koskemaan perheenhuoltajia, joiden tulo ja omaisuus on määrätyn rajan alapuolella. Sittemmin on omaisuusraja katsottu tarpeelliseksi poistaa, mutta tuloraja on jäljellä huolimatta kaikista niistä surullisista kokemuksista, joita inflaatiokautena siitä on saatu. Lopullinen ratkaisu ei voi olla mikään muu kuin perhelisän tekeminen yleiseksi. Näin on 
esim. verotuksessa jo aikoja sitten käynyt, vaikka tulo- ja omaisuusveron lapsivähennyksetkin aikanaan yritettiin rajoittaa alimpiin tuloluokkiin. Eihän tässä ole kysymys avustuksesta, vaan perhekustannusten tasoituksesta.

Perhelisän rinnalla on olemassa toisia tasoitusmuotoja, joiden merkitys on melkoinen. Tällainen on esim. koulukeittola ym. koululaitoksen oppilaille tarjoamat etuudet, jotka hyödyttävät perhettä sitä enemmän, mitä useampia lapsia se joutuu kouluun lähettämään. Tällä kollektiivisella linjalla meillä on vielä paljon tehtävää, ennenkuin esim. lastentarhoja ja lasten päiväkoteja on riittävästi, ennenkuin nuorten ammatinvalinnan ohjauksesta laaditut suunnitelmat on toteutettu jne.

Puhuttaessa väestöpolitiikan tehtävistä jälleenrakennuskauden aikana ei myöskään sovi unohtaa niitä tehtäviä, jotka kansanterveyden alalla odottavat. Sotavuosina ovat esim. tuberkuloosi ja monet muut kansantaudit entisestään levinneet ja tuhoavat kansamme elinvoimaa. Niiden tehokas ja päättävä vastustaminen on väestöpolitiikan tärkeimpiä tehtäviä. Samoin on työtä äitiyshuollon ja lastensuojelun alalla entisestään tehostettava. Kansan laadullista tasoa on vaalittava ja sitä varten $\mathrm{mm}$. sterilisaatiolaki uusittava. Niinikään tarvitaan rikollisten keskenmenojen vastustamiseksi sekä lainsäädännön uudistamista että tehokasta valistustoimintaa ja sosiaalisia tukitoimenpiteitä.

Väestöpolitiikan yleiseksi tavoitteeksi meidän maassamme on otettu kodin ja perheen saattaminen keskeiseen asemaan yhteiskunnassa. Jälleenrakennuskauden henkisiä virtauksia ajatellen on tässä yhteydessä syytä viitata suuren naapurimme Neuvostoliiton oloihin, koska me jälleenrakennuskauden aikana tulemme luonnostamme olemaan tämän maan kanssa paljon kiinteämmässä vuorovaikutuksessa kuin tähän asti ja koska sikäläinen yhteiskunnallisissa asioissa saavutettu kokemus epäilemättä tulee hyvin voimakkaasti vaikuttamaan siihen tapaan, jolla varsinkin työväestö meidän maassamme tässä esillä olevia yhteiskunnallisia probleemeja arvostelee.

Meidän maassamme tiedetään yleisesti, ettei Venäjällä kommunismin ottaessa ensimmäisiä askeleitaan valtiovallan haltijana perhesiteille annettu suurta arvoa. Niitä pidettiin kahleina, jotka 
on katkottava ja hävitettävä yhdessä porvarillisuuden rippeiden kanssa. Tämä oli kuitenkin vain alkuinnostusta, josta kokemuksen tietä on noustu todellisuuden kestävälle pohjalle. Maassamme ei vielä kaikkialla tiedetä, että perhesiteiden lujittaminen ei viime vuosina ole ollut päämääränä yksin meillä. Se on ollut sitä myös Neuvostoliitossa. Rekisteröimättömillä avioliitoilla ei siellä enää ole mitään pätevyyttä. Avioerot on tehty vaikeiksi. Jo kymmenkunta vuotta on Neuvostoliitossa toimittu tehokkaasti rikollisten keskenmenojen vastustamiseksi, vaikka meillä Suomessa edelleen varsin laajoissa pïreissä luullaan, että Venäjä on keskenmenojen luvattu maa. Samalla kun Neuvostoliitossa vastustetaan rikollisia keskenmenoja, tuetaan siellä kuten meilläkin lapsenkasvattajaa taloudellisesti. Verotus on myös tehty perheettömälle raskaammaksi, kuten hänen suurempi suorituskykynsä edellyttääkịn. Sanotaan, että taistelussa kansakunnan puolesta ei kukaan voi olla puolueeton.

$\mathrm{Ne}$ väestöpoliittiset tehtävät, jotka jälleenrakennuskauden aikana odottavat toteuttamistaan, ovat mittasuhteiltaan niin valtavat, että niiden. suorittamiseksi on koko kansa saatava valveille. Väestöpoliittinen valistustyö on ulotettava yhä laajempiin piireihin ja tämän kysymyksen keskeinen asema kaikessa yhteiskunnallisessa uudistustyössä selvitettävä jokaiselle kansalaiselle. Tästä syystä tämä kysymys kaipaa yhä uusia ja uusia valistuneita ja tietorikkaita puolestapuhujia.

Niitä kansalaisia varten, jotka haluavat täydentää omaa yhteiskunnallista sivistystään ja valmistua jakamaan sosiaalisia tietoja muillekin, on käsilläoleva Väestöliiton viisivuotisen toiminnan merkeissä syntynyt julkaisu toimitettu. Tässä johdantokirjoituksessa luodaan ensin yleiskatsaus väestöpolitiikan lähiaikojen tehtäviin. Seuraavassa artikkelissa annetaan lukijan tilaston pohjalla silmätä väestönkehityksemme tämänhetkistä tilaa. Senjälkeen tarkastel. laan, miten väestökysymỵken olemassaolo ja tärkeys maassamme vähitellen on opittu huomaamaan ja minkälaisiin toimenpiteisiin tämän asian hoitamiseksi meillä tähän mennessä on ryhdytty. Tarkoituksena on, että tätä ensimmäistä nidettä ja sen antamia tietoja myöhemmin voitaisiin vuosittain täydentää samanlaisella niteellä, jotta niillä, joita tämä keskeisin sosiaalinen kysymyksemme kiinnos- 
taa ja jotka haluavat sen kehitystä seurata jå.sen ratkaisuun myötävaikuttaa, olisi tilaisuus jatkuvasti nähdä, mitä tieteen ja käytännön yhteisin ponnisteluin vuoden kuluessa on selvitetty tai suoritettu.

Suomen kansa on saatava ymmärtämään, että väestöpolitiikka ei ole vain kysymystä suuremmasta tai pienemmästä lapsiluvusta, vaan että se on oleellinen osa valtion politiikkaa, osa, jonka tehtävä valtionruumiissa on aivan sama kuin terveydenhoidolla on yksityisen kansalaisen elämässä. Niinkuin terveydenhoidon tehtävänä on estää yksityinen kansalainen sortumasta ennenaikaiseen hautaan, niiin on väestöpolitiikan tehtävänä varjella kansaa samanlaiselta kohtalolta. Tämä tehtävä ei ole helppo. Se ei onnistunut antiikin kulttuurikansoille, vaan ne sortuivat. Se ei myöskään ole toistaiseksi onnistunut niille nykyisen länsimaisen kulttuurin piiriin kuuluville kansoille, jotka viime vuosikymmeninä ovat epäedullista väestönkehitystä vastaan taistelleet. Tällä ei kuitenkaan vielä ole todistettu, että tehtävä olisi mahdoton suorittaa. Päinvastoin on sanottava, että tässä on tehtävä, joka on kyllin arvokas kelvatakseen nuoren, elinvoimaiseksi itsensä tuntevan kansakunnan parhaitten pyrintöjen kohteeksi.

Me olemme nyt sotavuosien jälkeen paljon köyhempiä kuin ennen. Meidän mahdollisuutemme nostaa elintasoamme ovat toistaiseksi melkein olemattomat, mutta näissäkin oloissa meillä on joitakin mahdollisuuksia toteuttaa sosiaalisen oikeudenmukaisuuden vaatimusta ja nostaa niiden elintasoa, jotka elävät kaikkein vaikeimmissa oloissa. Meille on mahdollista nostaa Suomen suurten vähäväkisten perheiden elintasoa ja siten palkita näitten perheitten huoltajia siitä, mitä he vaikeinakin vuosina ovat tehneet ja päivästä toiseen tekevät maan ja kansan hyväksi. Ja vaikka emme voisi palkitakaan, voimme ainakin tehdä oikeutta. Se jo merkitsee heille sekä elintason nousua että henkistä rohkaisua. Viimeksimainittua ei ole syytä unohtaa eikä aliarvioida, sillä kaikkina aikoinahan on nähty, että uhraus yhteiskunnan hyväksi on helpompi tehdä, jos yhteiskunta ymmärtää uhrauksen arvon. 